\title{
Oxidative Stress Associated with Canine Leishmaniosis with Special Reference to Haemo-Biochemical Changes
}

\author{
Sabry A. Mousa ${ }^{1}$, Marwa M. Attia ${ }^{2 *}$, Arafat Khalphallah ${ }^{3}$, Noha Y. Salem ${ }^{1}$
}

${ }^{1}$ Department of Internal medicine and infectious diseases, Faculty of Veterinary Medicine, Cairo University, Giza, Egypt; ${ }^{2}$ Department of Parasitology, Faculty of Veterinary Medicine, Cairo University, Giza, Egypt; ${ }^{3}$ Division of Internal medicine ,Department of Animal Medicine, Faculty of Veterinary Medicine, Assiut University; Assiut, Egypt.

\begin{abstract}
The aim of this study is to identify the causative protozoan parasites infecting dogs in Egypt by discussing the clinical signs, hemato-biochemical, oxidative stress, and the pro-inflammatory markers alterations in Canine leishmaniosis (CanL). A total of 100 dogs of different breeds were collected from January to December 2020. The age of the dogs ranged between 3and 10 years. All the 100 dogs suffered from signs compatible with vector-borne diseases. Only one reported case was recorded for infection with CanL from 100 examined dogs ( $1 \%$ infection rate). The dog was 7 years old female German Sphered dog with significant weight loss, depression, pyrexia (temp $=40^{\circ}$ ), lameness on hind limbs, severe respiratory manifestations, and skin ecchymosis in the ventral abdomen, tail, and hind leg with lymphadenopathy. It had marked leukocytosis, neutrophilia, and monocytosis. Normocytic normochromic anemia and thrombocytopenia were also observed. The most important biochemical changes in the serum were mild hyperproteinemia, hypoalbuminemia, hyperglobulinemia, elevated liver and kidney function, elevation in C-reactive protein and malondialdehyde level and reduction in total antioxidant capacity.
\end{abstract}

Keywords | Canine leishmaniosis; C-reactive protein; Dog protozoa; Leishmania spp.; malondialdehyde

Received | March 08, 2021; Accepted | June 02, 2021; Published | August 15, 2021

*Correspondence | Marwa M. Attia, Department of Parasitology, Faculty of Veterinary Medicine, Cairo University, Egypt; Email: marwaattia.vetpara@yahoo.com, marwaattia.vetpara@cu.edu.eg

Citation | Mousa SA, Attia MM, Khalphallah A, Salem NY (2021). Oxidative stress associated with canine Leishmaniosis with special reference to haemobiochemical changes. Adv. Anim. Vet. Sci. 9(10): 1504-1510.

DOI | http://dx.doi.org/10.17582/journal.aavs/2021/9.10.1504.1510

ISSN (Online) | 2307-8316; ISSN (Print) | 2309-3331

Copyright $(9) 2021$ Mousa et al. This is an open access article distributed under the Creative Commons Attribution License, which permits unrestricted use, distribution, and reproduction in any medium, provided the original work is properly cited.

\section{INTRODUCTION}

$\mathrm{O}$ ne of the vector-borne diseases in dogs is canine leishmaniosis; a protozoan parasite transmitted mainly by sand fly (Phlebotomus papatasi) (Mauricio et al., 2018). When the cell-mediated response is deficient, propagation of the parasite occurs within macrophages of different tissues and organs (Paltrinieri et al., 2018). The disease has two main forms: cutaneous and visceral caused by members of the Leishmania genus mainly $L$. infantum and $L$. chagasi (Silva, 2007; Montargil et al., 2018). Canine leishmaniasis prevails in the old and new world (Latif et al., 2019). In Egypt, reports suggest the foci of leishmaniasis present in the Suez-canal area and Sinai Peninsula (Bessat et al.2015). Though, the disease appears endemic in north Africa and the middle east, little information available about it in Egypt (Rosypal et al., 2013).

Variable clinical signs have been described including, cutaneous changes, enlargement of lymph nodes, glomerulonephritis, and uveitis consequent to immune-complex deposition (Maia and Campino, 2018).

Canine leishmaniosis is caused by Leishmania spp and it is considered an important zoonotic disease (Ahmadi-Hamedani et al., 2020). The severity of the disease ranged from mild self-healing skin form to more severe and may be a fatal form (Dumonteil et al., 2003). The parasite 
itself, the immune status, and the genes are all factors affecting the severity of the disease (Ribeiro et al., 2018). Two main systems were established for the accurate diagnosis of canine leishmaniasis, namely, LeishVet and canine leishmaniasis working group (Proverbio, 2016). The first one depends mainly on physical findings, indirect fluorescent antibody (IFT) level, and hemato-biochemical findings (Ribeiro et al., 2018). The second one depends on clinical status, cytology, PCR/histology in addition to laboratory findings (Roura et al., 2013; Paltrinieri et al., 2010).

Canine leishmaniasis (CanL) is associated with a wide range of hematobiochemical alterations, with normocytic-normochromic anemia, neutrophilia, thrombocytopenia, hypoalbuminemia, hyperglobulinemia, and elevated renal/ hepatic parameters as common laboratory findings (Maia and Campino, 2018; Ribeiro et al., 2018; Ahmadi-Hamedani et al., 2020).

This study aims to identify the causative protozoan parasites infecting dogs in Egypt by discussing the clinical signs, hemato-biochemical profiles, oxidative stress, and pro-inflammatory markers alterations in CanL suspected dogs.

\section{MATERIALS AND METHODS}

\section{Sample Collection}

A total number of 100 dogs of different breeds with fever, anorexia, and lymphadenopathy were collected from January to December 2020. The age of the dogs ranged between 3-10 years. Blood samples were collected from the cephalic vein for Complete Blood Count (CBC) and serum was obtained for the determination of biochemical parameters (Zaki et al., 2021). The examined dogs were admitted to the private veterinary clinic in Giza Governorate, Egypt.

\section{Parasitological Examination}

The blood (with EDTA) was used for preparing fixed smears with methanol and stained with Giemsa stain (Attia and Mahdy, 2021). The stained blood smears were examined under the microscope $(\times 400$ and $\times 1000$; OLYMPUS CX41) for detection of Leishmania spp (Attia et al., 2018; Zaki et al., 2021).

\section{Hematological and Biochemical Analysis of Blood and Sera of Dogs Infected With LEISHMANLA SPP}

The whole blood with EDTA underwent hematological analysis to determine different blood parameters changed during Leishmania spp infection in dogs. Serum was analyzed for the determination of total protein, albumin, ALT (Alanine amino transferase), AST
(Aspratate amino transferase), AP (Alkaline phosphatase), cholesterol, triglycerides, creatinine, blood urea nitrogen (BUN), and C-reactive protein (CRP) using specific test kits (Attia et al., 2020).

\section{Measurement of Oxidative Stress Markers}

The collected sera samples from the infected dogs were subjected to analysis of malondialdehyde (MDA) and TAC (Total antioxidant capacity), using specific kits according to manufacture (Attia et al., 2020; Abdelkader et al., 2021).

\section{Prevalence}

Prevalence of affection was calculated according to the equation described by Whiting et al. (2015) as follow;

$$
\text { Prevalence }=\frac{\text { Number of fected cases }}{\text { Number of examined animals }}
$$

\section{RESULTS AND DISCUSSION}

Canine leishmaniasis is a vector-borne zoonotic disease with multisystem involvement (Mauricio et al., 2018). In this investigation out of examined 100 dogs with signs compatible with vector-borne diseases, the overall prevalence was $1 \%$. Though, the disease appears endemic in north Africa and the middle east, little information available about it in Egypt (Rosypal et al., 2013).

Out of 100 dogs presented with fever, anorexia, and lymphadenopathy, only one dog was positive for Leishmania $s p p$ with an overall prevalence of $1 \%$. The heamatological , biochemical and oxidative stress bio markers of non-infected leishmania dogs (control group $=99$ ) were tabulated in (Table 1).

Only one case was recorded for infection with Canine leishmaniosis from 100 examined dogs (1\% infection rate). The dog was a 7 years old female German Sphered dog with significant weight loss, depression, pyrexia (temp $=40^{\circ}$ ), lameness on hind limbs, severe respiratory manifestations, and skin ecchymosis in the ventral abdomen, tail, and hind legs (Figure 1). Lymphadenopathy was found on physical examination. The Leishmania spp amastigotes were observed in microscopical evaluation of blood smears (Figure 2).

The dog has signs associated with different body organs. Dermatologic lesions were apparent as well as lymphadenopathy. These signs are consistent with cutaneous-visceral form. In classic cutaneous-visceral form, lymphadenopathy, followed by cutaneous lesions as non-pruritic dermatitis (with/ without alopecia), erosive/ulcerative/nodular or pustular 


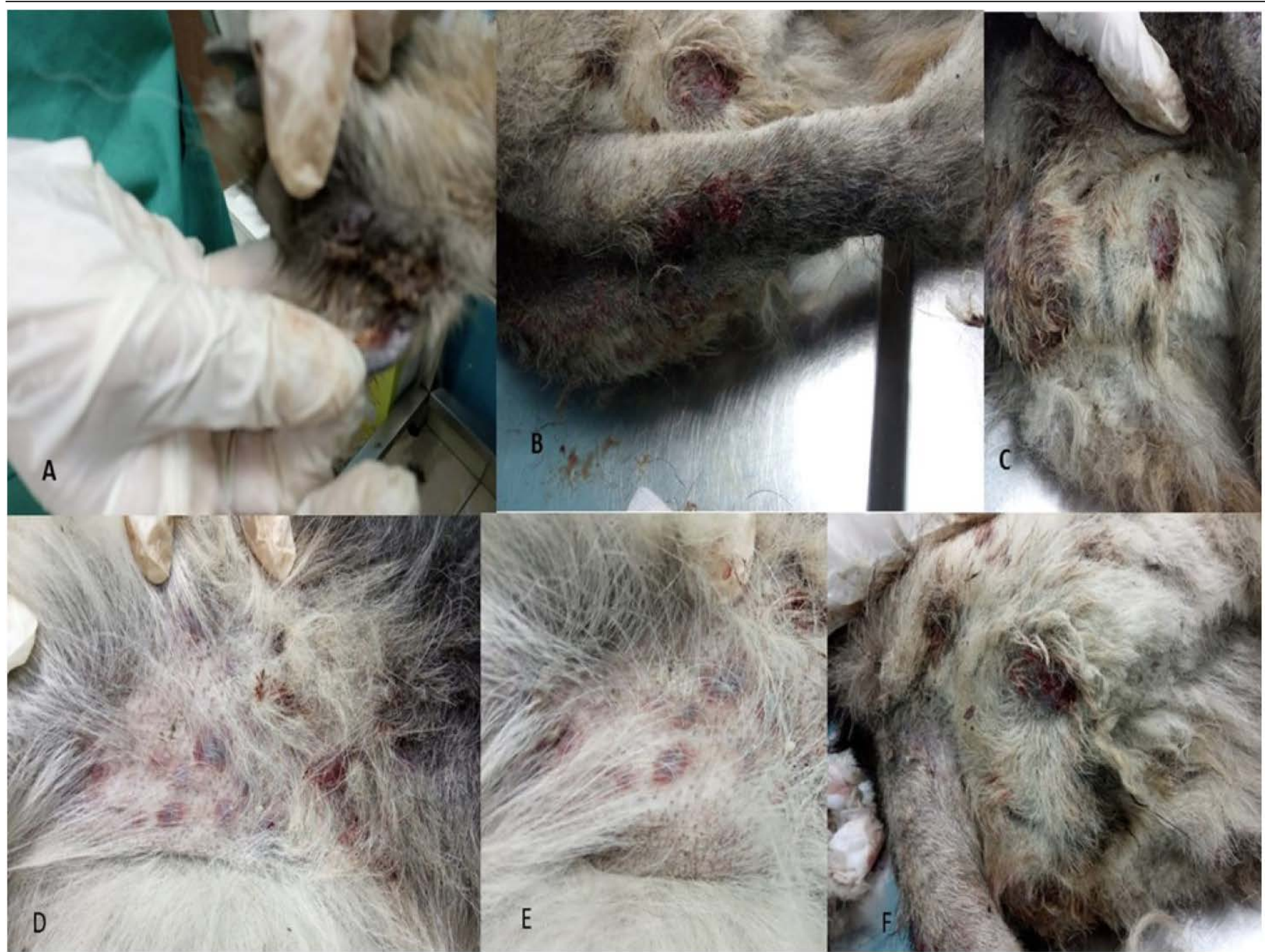

Figure 1: Clinical Signs of Dog Infected with Canine Leishmaniosis Reveals Several Skin Ecchymosis in Ventral Abdomen, Tail and Hind Legs with Lymphadenopathy.

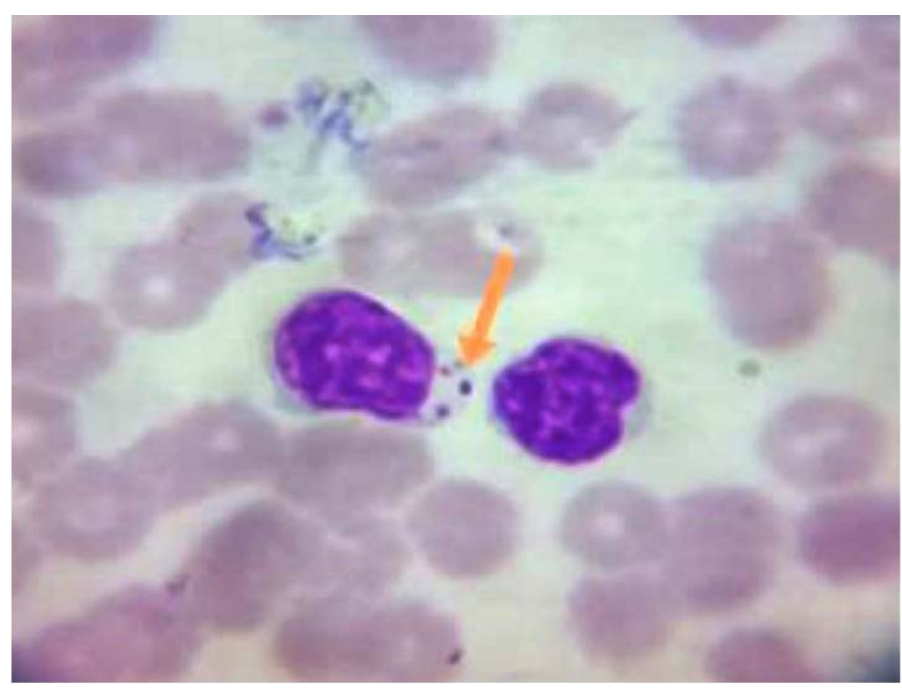

Figure 2: Blood Smear From Infected Dogs With Canine Leishmaniosis Stained with Giemsa Reveals Presence of Amastigote form of Leishmania Spp. Inside the Macrophage (Showed by Arrow).

dermatitis, and depigmentation (Lima et al., 2004; Roura et al., 2013; Koutinas et al., 2014; Ordeix et al., 2017).
Diagnosis of CanL is a complex process as the clinical signs are not present in all infected dogs (Mancianti et al.,1988). Sometimes, atypical signs such as arthritis may be present (Sbrana et al., 2014). Because of the multisystem nature of the disease, the diagnosis of the disease should not depend only on clinical and physical findings (Montargil et al., 2018; Saad and Attia, 2020).

Hematological examination revealed marked leukocytosis, neutrophilia, and monocytosis. Normocytic normochromic anemia and thrombocytopenia were also observed (Table 1).

The main alterations in hematology were a reduction in $\mathrm{RBCs}, \mathrm{HB}$, and $\mathrm{PCV}$ percentage, these alterations were reported in association with leishmania infections (Montargil et al., 2018). Normocytic normochromic anemia has been extensively reported (Paltrinieri et al., 2016). This type of anemia is usually seen in chronic conditions (Maia and Campino, 2018).

A reduction in erythropoiesis by bone marrow or consequent to renal disease with an expected reduction in eryth- 
ropoietin hormone, or hemolysis may be implicated (Maia and Campino, 2018). Though some reports showed normocytic hypochromic anemia (Torrecilha et al., 2016), and iron deficiency could be implicated (Jain, 1986).

Table 1: Hematological Parameters in LEISHMANIA Non -Infected Dogs ( Control Group) and LeishmaniaInfected dog Compared to Normal Reference Range.

\begin{tabular}{|c|c|c|c|c|c|}
\hline \multirow[t]{2}{*}{ Parameter } & \multicolumn{3}{|c|}{$\begin{array}{l}\text { Non-infected dog (con- } \\
\text { trol group=99) }\end{array}$} & \multirow{2}{*}{$\begin{array}{l}\text { Dis- } \\
\text { eased } \\
\text { dog }\end{array}$} & \multirow{2}{*}{$\begin{array}{l}\text { Reference } \\
\text { range* } \\
\text { (SI units) }\end{array}$} \\
\hline & $\mathrm{M} \pm \mathrm{SE}$ & $\begin{array}{l}\text { Mini- } \\
\text { mum } \\
\text { Value }\end{array}$ & $\begin{array}{l}\text { Maxi- } \\
\text { mum } \\
\text { Value }\end{array}$ & & \\
\hline $\mathrm{RBCs}\left(\times 10^{12} / \mathrm{L}\right)$ & $7 \pm 0.09$ & 5.40 & 8.50 & 4.09 & $5.5-8.5$ \\
\hline PCV & $\begin{array}{l}0.46 \pm \\
0.60\end{array}$ & 0.38 & 0.58 & 0.31 & $0.37-0.55$ \\
\hline $\mathrm{HB}(\mathrm{g} / \mathrm{l})$ & $\begin{array}{l}155.6 \pm \\
0.15\end{array}$ & 129 & 186 & 104 & $120-180$ \\
\hline $\mathrm{MCV}(\mathrm{fl})$ & $\begin{array}{l}66.79 \pm \\
1.19\end{array}$ & 49.24 & 99.31 & 75.7 & $60-77$ \\
\hline $\mathrm{MCHC}(\mathrm{g} / \mathrm{l})$ & $\begin{array}{l}340.2 \pm \\
0.31\end{array}$ & 263.8 & 457.7 & 335.4 & $320-360$ \\
\hline $\begin{array}{l}\text { Thrombocytes } \\
\left(10^{3} / \mu \mathrm{L}\right)\end{array}$ & $\begin{array}{l}199.01 \pm \\
2.72\end{array}$ & 160.30 & 250 & 122 & $160-430$ \\
\hline $\begin{array}{l}\text { WBCS }\left(10^{3 /}\right. \\
\mu \mathrm{L})\end{array}$ & $\begin{array}{l}9.48 \pm \\
0.14\end{array}$ & 7.20 & 12.30 & 17.590 & $6-17$ \\
\hline $\begin{array}{l}\text { Neutrophils } \\
\left(10^{3} / \mu \mathrm{L}\right)\end{array}$ & $\begin{array}{l}8.68 \pm \\
0.11\end{array}$ & 3 & 10.30 & 12.840 & $3-11.5$ \\
\hline $\begin{array}{l}\text { Lymphocytes } \\
\left(10^{3} / \mu \mathrm{L}\right)\end{array}$ & $\begin{array}{l}3.34 \pm \\
0.05\end{array}$ & 2.20 & 4.20 & 2.638 & $1-4.8$ \\
\hline $\begin{array}{l}\text { Monocytes } \\
\left(10^{3} / \mu \mathrm{L}\right)\end{array}$ & $\begin{array}{l}1.42 \pm \\
0.005\end{array}$ & 1.31 & 1.51 & 1.759 & $1.350-1.50$ \\
\hline $\begin{array}{l}\text { Eosinophils } \\
\left(10^{3} / \mu \mathrm{L}\right)\end{array}$ & $\begin{array}{l}1.44 \pm \\
0.04\end{array}$ & 1.31 & 1.51 & 3.518 & $1.350-1.50$ \\
\hline
\end{tabular}

*Reference values were extracted from 'Jain, 1986; Kaneko et al., 1997; Todorova et al., 2005; Willard and Tvedton, 2012 and Almeida et al., 2013.

Leukocytosis, neutrophilia, and monocytosis were detected in the affected dog. The response of the body to various organ assaults and inflammation by the parasite is neutrophilia (Torrecilha et al., 2016). 'Zandbergen et al. (2004) described the neutrophil in Leishmania infection as "trojan-horse". The elevation in both leucocytes and neutrophils could be attributed to secondary bacterial infection or the over-activation of the cellular immune response at this point overrules leucocyte destruction (Montargil et al., 2018). Thrombocytopenia was another finding in hematological alterations, and it was described in association with Leishmania infection (Paltrinieri et al., 2016). The reported hematologic parameters varied in previous reports, for instance, Paltrinieri et al. (2010) reported Macrocytic-hypochromic anemia, monocytosis, leukopenia, neutrophilia, proteinuria, and thrombocytopathy; the same type of anemia was also reported by Melendez-Laso et al. (2018). However, Ahmadi-Hamedani et al. (2020) reported Anemia, neutrophilia, monocytosis, and leukocytosis. Moreover, Torrecilha et al. (2016) reported Non-regenerative anemia, eosinopenia, and neutrophilia.

Table 2: Serum Biochemistry, Oxidative Stress, and Inflammatory Biomarkers In Leishmania Non -Infected Dog (Control Group) and Leishmania-Infected Dog Compared to Normal Reference Range.

\begin{tabular}{|c|c|c|c|c|c|}
\hline \multirow[t]{2}{*}{ Parameter } & \multicolumn{3}{|c|}{$\begin{array}{l}\text { Non-infected dog }(\text { con- } \\
\text { trol group }=99)\end{array}$} & \multirow{2}{*}{$\begin{array}{l}\text { Dis- } \\
\text { eased } \\
\text { dog }\end{array}$} & \multirow{2}{*}{$\begin{array}{l}\text { Reference } \\
\text { range* } \\
\text { (SI units) }\end{array}$} \\
\hline & $\mathrm{M} \pm \mathrm{SE}$ & $\begin{array}{l}\text { Mini- } \\
\text { mum } \\
\text { Value }\end{array}$ & $\begin{array}{l}\text { Maxi- }^{-} \\
\text {mum } \\
\text { Value }\end{array}$ & & \\
\hline $\mathrm{TP}(\mathrm{g} / \mathrm{L})$ & $\begin{array}{l}63.2 \pm \\
0.07\end{array}$ & 51 & 75 & 72.8 & $54-71$ \\
\hline Albumin (g/l) & $\begin{array}{l}28.80 \pm \\
0.02\end{array}$ & 24 & 33 & 20.8 & $26-33$ \\
\hline Globulin(g/l) & $\begin{array}{l}34.4 \pm \\
0.07\end{array}$ & 18 & 51 & 52 & $27-44$ \\
\hline $\mathrm{A} / \mathrm{G}$ ratio & $\begin{array}{l}0.89 \pm \\
0.02\end{array}$ & 0.47 & 1.83 & 0.4 & \\
\hline ALT $(\mu \mathrm{kat} / \mathrm{L})$ & $\begin{array}{l}0.90 \pm \\
2.08\end{array}$ & 0.33 & 1.54 & 1.62 & $0.17-1.57$ \\
\hline $\mathrm{AST}(\mu \mathrm{kat} / \mathrm{L})$ & $\begin{array}{l}0.88 \pm \\
0.77\end{array}$ & 0.67 & 1.10 & 1.41 & $0.38-1.10$ \\
\hline ALP $(\mu k a t / L)$ & $\begin{array}{l}2.27 \pm \\
0.95\end{array}$ & 2 & 2.54 & 3.40 & $0.33-2.61$ \\
\hline $\begin{array}{l}\text { Cholesterol } \\
(\mathrm{mmol} / \mathrm{L})\end{array}$ & $\begin{array}{l}5.94 \pm \\
1.20\end{array}$ & 5.44 & 6.50 & 5.53 & $3.50-6.99$ \\
\hline $\begin{array}{l}\text { Triglycer- } \\
\text { ides }(\mathrm{mmol} / \mathrm{L})\end{array}$ & $\begin{array}{l}1.12 \pm \\
0.58\end{array}$ & 1.02 & 1.24 & 1.11 & $0.23-127$ \\
\hline $\begin{array}{l}\text { BUN } \\
(\mathrm{mmol} / \mathrm{L})\end{array}$ & $\begin{array}{l}15.84 \pm \\
0.91\end{array}$ & 10.71 & 21.42 & 21.78 & $3.57-17.85$ \\
\hline $\begin{array}{l}\text { Creatinine } \\
(\mu \mathrm{mol} / \mathrm{L})\end{array}$ & $\begin{array}{l}58.34 \pm \\
0.01\end{array}$ & 44.20 & 78.68 & 147.63 & $\begin{array}{l}44.20- \\
123.76\end{array}$ \\
\hline $\mathrm{CRP}(\mathrm{mg} / \mathrm{l})$ & $\begin{array}{l}30.5 \pm \\
0.12\end{array}$ & 10 & 60 & 180 & $\leq 60$ \\
\hline $\begin{array}{l}\mathrm{TAC}(\mathrm{m} \\
\mathrm{mole} / \mathrm{L})\end{array}$ & $\begin{array}{l}0.95 \pm \\
0.003\end{array}$ & 0.90 & 1 & 0.608 & $0.9-1$ \\
\hline $\begin{array}{l}\mathrm{MDA}(\mathrm{m} \\
\mathrm{mole} / \mathrm{L})\end{array}$ & $\begin{array}{l}1.13 \pm \\
0.05\end{array}$ & 0.60 & 2.30 & 2.872 & $0.659-2.5$ \\
\hline
\end{tabular}

*Reference values were extracted from 'Jain, 1986; Kaneko et al., 1997; Todorova et al., 2005; Willard and Tvedton, 2012 and Almeida et al., 2013.

The present study reported elevation of serum activities of ALT, AST, and ALP in dogs with leishmaniasis compared with the reference value. The serum concentration of blood urea nitrogen was slightly increased, also there was a slight elevation in MDA levels (Table 2).

A slight elevation in total protein along with a reduction in 
albumin and elevated globulin were recorded. Elevated liver and kidney markers were also observed. Alterations in liver enzymes, azotemia, and disruption in protein balance, with elevation in protein caused by elevated globulin, caused mainly by the response of polyclonal $\mathrm{B}$ cell and reduction of albumin caused by hepatocyte damage and renal disease (Heidarpour et al., 2012; Salem et al., 2014; Ribeiro et al., 2013; Paltrinieri et al., 2016). Elevation in renal parameters was observed. In another protozoan model (Babesia), it was believed that renal degeneration with subsequent necrosis could play a role in elevated renal parameters (Mosqueda et al., 2012). A non-kidney-related elevation could be also implicated as a result of hemorrhage and hemolysis (Reyes et al., 1998). CanL is associated with glomerulonephritis, a disease of the kidney associated with alterations in renal parameters (Maia and Campino, 2018). Increased levels of liver enzymes are consistent with liver injury (Graham et al., 2003; Ramadan et al., 2019).

\section{Oxidative Stress Parameters}

Elevated MDA and reduction in TAC were recorded. Lipid peroxidation products as MDA elicits an oxidative stress process which in turn, exacerbates the inflammation (Abdelnaby et al., 2020). As the disease progress, apoptosis of cells increases, and antioxidant components of neutrophils will be reduced (Almeida et al., 2013a). Torrecilha et al. (2016) observed a positive correlation between parasitic load and TAC. TAC is used as an easy and inexpensive way to give a crude idea about antioxidant status in the body (Abdel-Saeed and Salem, 2019). Leishmania causes oxidative stress (Maia and Campino, 2018), at the site of inflammation, phagocytes will release reactive oxygen spp. (ROS), leading to activation of antioxidant components, which will be consumed in fighting formed ROS (Torrecilha et al., 2016; Kubesy et al., 2017; Elsayed et al., 2020). This mechanism is hypothesized as a way for the parasite to elude the body's immune system (Torrecilha et al., 2016). 'Heidarpour et al. (2012) observed an elevation in the oxidant side and reduction in the antioxidant side in dogs with clinical signs.

\section{Pro-Inflammatory Markers}

Changes in an acute phase proteins (APPs) were observed with elevated positive APP (CRP) and reduction in negative APP (albumin); these alterations were recorded in Martinez-Subiela et al. (2014), Paltrinieri et al. (2016). Hypoalbuminemia is considered a negative prognostic marker (Paltrinieri et al., 2016).

\section{CONCLUSION}

Cuteno-visceral form of Canine leishmaniasis (CanL) is associated with marked hemato-biochemical alterations, oxidative stress, and disruption of pro-inflammatory markers. No specific treatment to CanL but symptomatic treat- ment is recommended with control of the vector of the protozoan parasites.

\section{AUTHORS CONTRIBUTION}

All authors have made substantial contribution in conception and design of the study. They have been involved in drafting, revising and final approval of the manuscript. Marwa M. Attia identified and photographed the parasites.

\section{CONFLICT OF INTEREST}

The authors declare that they have no conflict of interest. No funding was supporting this work.

\section{REFERENCES}

-Abdelatief NA, Krüger A, Mans BJ (2019). Risk of establishment of canine leishmaniasis infection through the import of dogs into South Africa. Onderstepoort J. Vet. Res. 28; 86(1): e1e11. https://doi.org/10.4102/ojvr.v86i1.1634

- AbdElKader NA, Sheta E, AbuBakr HO, others (2020). Effects of chitosan nanoparticles, ivermectin and their combination in the treatment of Gasterophilus intestinalis (Diptera: Gasterophilidae) larvae in donkeys (Equus asinus). Int. J. Trop. Insect Sci. http://dx.doi.org/10.1007/s42690-02000171-2.

- Abdel-Saeed H,Salem NY (2019). Evaluation of total antioxidant capacity, malondialdehyde, catalase, proteins, zinc, copper and $\mathrm{IgE}$ response in ovine verminous pneumonia. Int. J. Vet. Sci. (2019) 8:255-8.

-Abdelnaby EA, Emam IA, Salem NY, Ramadan ES, Khattab MS, Farghali HA, Abd El Kader NA (2020). Uterine hemodynamic patterns, oxidative stress, and chromoendoscopy in mares with endometritis. Theriogenology. 2020 158:112120. https://doi.org/10.1016/j.theriogenology.2020.09.012

- AbdElKader NA, Sheta E, AbuBakr HO, El-Shamy OAA, Oryan A,Attia MM (2020). Effects of chitosan nanoparticles, ivermectin and their combination in the treatment of Gasterophilus intestinalis (Diptera: Gasterophilidae) larvae in donkeys (Equus asinus). Int. J. Trop. Insect Sci. https://doi. org/10.1007/s42690-020-00171-2

- Ahmadi-Hamedani M,Hosseinpour H,Eskafian H,Davarpanah Davarpanah S. (2020). The Hematological and Biochemical Manifestations of Cutaneous Leishmaniasis in a Shih TzuTerrier Dog with Severe Infection: A Case Report. Iran. J. Parasitol: 15 (3): 457-462. https://doi.org/10.18502/ijpa. v15i3.4213

- Alexa CR, Shañae SB, Samuel AE, AM El Behairy, M Hilali, JP Dubey (2013). Serological survey of dogs from egypt for antibodies to Leishmania Species. J. Parasitol. 99 (1): 170171. https://doi.org/10.1645/GE-3242.1

-Almeida BFM, Narciso LG, Melo LM, Preve PP, Bosco AM, Lima VMF, Ciarlini PC (2013). Leishmaniasis causes oxidative stress and alteration of oxidative metabolism and viability of neutrophils in dogs. Vet. J. 198: 599-605. https:// doi.org/10.1016/j.tvj1.2013.08.024

-Almeida BF, Silva KL, Chiku, VM, Leal, AA., Venturin G, Narciso L (2017). The effects of increased heme oxygenase-1 on the lymphoproliferative response in dogs with visceral leishmaniasis. Immunobiology. 222: 693-703. https://doi. 
org/10.1016/j.imbio.2016.12.006

- Almeida BFM, Narciso LG, Bosco AM, Pereira PP, Braga ET, Avanc oSV, Marcondes M, Ciarlini PC (2013a). Neutrophil dysfunction varies with thestage of canine visceral leishmaniosis. Vet. Parasitol. 196: 6-12. https://doi. org/10.1016/j.vetpar.2013.02.016

-Attia MM, Mahdy OA (2021). Evaluation of the cell mediated immune responses using quantitative Real-time Polymerase Chain Reaction during the infestation of Rhinoestrus usbekistanicus (Diptera: Oestridae) in equine. Int. J. Trop. Insect Sci. https://doi.org/10.1007/s42690-021-00509-4

-Attia MM, Khalifa MM, Atwa MT (2018). The prevalence and intensity of external and internal parasites in working donkeys (Equus asinus) in Egypt. Vet World. 11(9): 12981306. https://doi.org/10.14202/vetworld.2018.1298-1306

-Attia MM, El-Gameel SM, Ismael E (2020). Evaluation of tumor necrosis factor-alpha (TNF-a); gamma interferon $(\mathrm{IFN}-\mathrm{c})$ genes and oxidative stress in sheep: Immunological responses induced by Oestrus ovis (Diptera: Oestridae) infestation. J. Parasit. Dis. 44(2): 332-337. https://doi. org/10.1007/s12639-020-01220-w

-Bessat M, Okpanma AC, Shanat ES (2015). Leishmaniasis: Epidemiology, Control and Future Perspectives with Special Emphasis on Egypt. J. Trop. Dis. 2: 153.

-Dumonteil ER, Jesus SM, Javier EO, GMMD Rosario (2003). DNA vaccines induce partial protection against Leishmania mexicana. Vaccine. 21 (17-18): 2170-2177. https://doi. org/10.1016/S0264-410X(02)00769-7

-Elsayed NM, Kubesy AA, Salem, NY (2020). Altered blood oxidative stress biomarkers in association with canine parvovirus enteritis. Comp. Clin. Pathol. 29: 355-359. https://doi.org/10.1007/s00580-019-03067-x

- Geisweid K, Mueller R, SauterLouis C, Hartmann K (2012). Prognostic analytes in dogs with Leishmania infantum infection living in a non-endemic area. Vet. Rec. 171: 399. https://doi.org/10.1136/vr.100637

- Graham MJ, Bell AR, Crewe HK, Moorcraft CL, Walker L, Whittaker EF, Lennard MS (2003). mRNA and protein expression of dog liver cytochromes $\mathrm{P} 450$ in relation to the metabolismofhumanCYP2Csubstrates.Xenobiotica.33:225237. https://doi.org/10.1080/0049825021000048782

- Heidarpour M, Soltani S, Mohri M, Khoshnegah J (2012). Canine visceral leishmaniasis: Relationships between oxidative stress, liver and kidney variables, trace elements, and clinical status," Parasitol Res, 111 (4), 1491-1496. https://doi.org/10.1007/s00436-012-2985-8

-Jain NC (1986). Schalm's veterinary hematology, 4th ed. Lea \& Febiger, Philadelphia.

-Kaneko JJ, Harvey JW, Bruss ML (1997). Clinical Biochemistry of Domestic Animals, 5th ed. Academic Press, California.

-Koutinas AF, Koutinas CK (2014). Pathologic mechanisms underlying the clinical findings in canine Leishmaniosis due to Leishmania infantum/chagasi, Vet. Pathol. 51: 2: 527-538. https://doi.org/10.1177/0300985814521248

-Kubesy AA, Salem NY, Jaheen AH (2017). Altered blood oxidative stress biomarkers in association with canine pyoderma and allergic contact dermatitis. Comp. Clin. Pathol. 26: 643-646. https://doi.org/10.1007/s00580-0172418-2

-Latif AA, Nkabinde B, Peba B, Matthee O, Pienaar R, Josemans A, Marumo D, Labuschagne K, Martinez-Subiela S, Cerón J, Strauss-Ayali D, Garcia-Martinez J, Tecles F, Tvarijonaviciute A, Caldin M, Baneth G (2014). Serum ferritin and paraoxonase-1 in canine leishmaniosis. Comp. Immunol. Microbiol. Infect. Dis. 37: 23-29. https://doi. org/10.1016/j.cimid.2013.10.004

-LimaWG,Michalick MSM,Melo MND,TafuriW L, Tafuri WL (2004). Canine visceral leishmaniasis: A histopathological study of lymph nodes. Acta Tropica. 92 (1): 43-53. https:// doi.org/10.1016/j.actatropica.2004.04.007

- Maia C, Campino L (2018). Biomarkers associated with Leishmania infantum Exposure, Infection, and Disease in Dogs. Front. Cell. Infect. Microbiol. 8:302. https://doi. org/10.3389/fcimb.2018.00302

-Martínez-Subiela S, Bernal LJ, Tvarijonaviciute A, GarciaMartinez JD, Tecles F, Cerón JJ (2014), Canine demodicosis: the relationship between response to treatment of generalised disease and markers for inflammation and oxidative status. Vet. Dermatol. 25: 72-e24. https://doi.org/10.1111/ vde. 12108

-Mancianti F, Gramiccia M, Gradoni L, Pieri S (1988). Studies on canine leishmaniasis control. 1. Evolution of infection of different clinical forms of canine leishmaniasis following antimonial treatment, Trans. R. Soc. Trop. Med. Hyg. 82 (4): 566-567. https://doi.org/10.1016/0035-9203(88)90510-X

-Mosqueda J, Olvera-Ramirez A, Aguilar-Tipacamu G, Canto GJ (2012). Current advances in detection and treatment of babesiosis. Curr. Med. Chem. 19: 1504-1518 https://doi. org/10.2174/092986712799828355

- Mauricio I (2018). Leishmania taxonomy, in The Leishmaniases: Old Neglected Tropical Diseases, 1st Edn, eds F. Bruschi and L. Graadoni (Vienna: Springer Verlag), 15-30. https://doi. org/10.1007/978-3-319-72386-0_2

-Meléndez-Lazo A, Ordeix L, Planellas M, Pastor J, SolanoGallego L (2018). Clinicopathological findings in sick dogs naturally infected with Leishmania infantum: comparison of five different clinical classification systems. Res. Vet. Sci. 117: 18-27. https://doi.org/10.1016/j.rvsc.2017.10.011

- Montargil SM, Carvalho AFS, Oliverira MS (2018). Clinical, Hematological and Biochemical Profiles of Dogs with Leishmania infantum. Acta. Sci. Vet. 46: 1548. https://doi. org/10.22456/1679-9216.82065

- Ordeix L, Dalmau A, Osso M, Llull J, Montserrat-Sangr`a S, Solano-Gallego L (2017). Histological and parasitological distinctive findings in clinically-lesioned and normal-looking skin of dogs with different clinical stages of leishmaniosis. Parasit Vectors. 10 (1): 121. https://doi.org/10.1186/s13071017-2051-6

-Paltrinieri S, Solano-Gallego L, Fondati A (2010). Guidelines for diagnosis and clinical classification of leishmaniasis in dogs. J. Am. Vet. Med. Assoc. 236( 11): 1184-1191. https:// doi.org/10.2460/javma.236.11.1184

-Paltrinieri S, Gradoni L, Roura X, Zatelli A, and Zini, E (2016). Laboratory tests for diagnosing and monitoring canine leishmaniasis," Veterinary Clinical Pathology, 45, 4, 552- 578. https://doi.org/10.1111/vcp.12413

- Paltrinieri S, Mangiagalli G, Ibba F (2018). Use of urinary $\gamma$-glutamyl transferase to monitor the pattern of proteinuria in dogs with leishmaniasis treated with $\mathrm{N}$-methylglucamine antimoniate. Res. Vet. Sci. 119: 52- 55

- Proverbio D, Spada E, de Giorgi GB et al. (2016). Proteinuria reduction after treatment with miltefosine and allopurinol in dogs naturally infected with leishmaniasis. Vet. World. 9: 904- 908 .

- Ramadan ES, Kubesy AA, Baraka TA, Torad FA, Salem SI, Salem NY (2019). Expression of blood hepatocyte-derived 
microRNA-122 in canine multicentric lymphoma with hepatic involvement. Vet. Res. Commun. 43(4):231-238. https://doi.org/10.1007/s11259-019-09764-w

- Reyers F, Leisewitz AL, Lobetti RG, Milner RJ, Jacobson LS (1998). Canine babesiosis in South Africa: more than one disease. Does this serve as a model for falciform malaria? Ann. Trop. Med. Parasitol. 92:503-51. https://doi.org/10.1 080/00034983.1998.11813308

- Ribeiro RR, Silva SM, Fulg^encio GD, Michalick MS, Fr'ezard, FJ (2013). Relationship between clinical and pathological signs and severity of canine leishmaniasis, Revista Brasileira de Parasitologia Veterin'aria. 22 (3):373-378. https://doi. org/10.1590/S1984-29612013000300009

- Ribeiro RR, Michalick MSM, da Silva ME (2018). Canine Leishmaniasis: An Overview of the Current Status and Strategies for Control. Biomed. Res. Int. 3296893. https:// doi.org/10.1155/2018/3296893

-Rosypal AC, J Francis, S Tripp, S Lewis M, K Stoskopf, DS Lindsay (2010). Survey of antibodies to Trypanosoma cruzi and Leishmania spp. in gray and red fox populations from North Carolina and Virginia. J. Parasitol. 96: 1230-1231.

- Roura X, Fondati A, Lubas G (2013). Prognosis and monitoring of leishmaniasis in dogs: A working group report. Vet. J. 198 (1): 43-47. https://doi.org/10.1016/j.tvj1.2013.04.001

-Saad MF, Attia MM (2020). Milk As a New Diagnostic Tool for Rapid Detection of Fascioliasis in Dairy Goats Using Excretory/Secretory Antigen. Acta Parasit. https://doi. org/10.1007/s11686-020-00286-Z

-Salem N, Rakha G, Baraka T. (2014). Naturally occurring ehrlichiosis in Egyptian dogs. Iran. J. Vet. Res. 15:54-57.

-Sbrana S, Marchetti V, Mancianti F, Guidi G, Bennett D (2014).
Retrospective study of 14 cases of canine arthritis secondary to Leishmania infection. J. Small Anim. Pract. 55 (6): 309313. https://doi.org/10.1111/jsap.12204

-Silva FS (2007). Patologia e patogênese da leishmaniose visceral canina. Revista Trópica-Ciências Agrárias e Biológicas. 1(1): 20.

-Todorova I, Simeonova G, Kyuchukova D (2005). Reference values of oxidative stress parameters (MDA, SOD, CAT) in dogs and cats. Comp. Clin. Path. 13: 190-194. https://doi. org/10.1007/s00580-005-0547-5

-Torrecilha RBP, Utsunomiya YT, Bosco AM (2016). Correlations between peripheral parasite load and common clinical and laboratory alterations in dogs with visceral leishmaniasis. Prev. Vet. Med. 132:83-87. https://doi.org/10.1016/j. prevetmed.2016.08.006

-Whiting PF, Davenport C, Jameson C, Burke M, Sterne JA, Hyde C, Ben-Shlomo Y (2015) How well do health professionals interpret diagnostic information? A systematic review. BMJ Open. 5(7): e008155. https://doi.org/10.1136/ bmjopen-2015-008155

-Willard MD, Tvedton H (2012). Small animal medical diagnosis by laboratory methods, 5 th edn

-Zandbergen G, Van Klinger M, Mueller A, Gebert A, Solbach W, Alerts E (2004). Cutting edge: neutrophil granulocyte serves as a vector for leishmania entry into macrophages. J. Immunol. 173: 6521-6525. https://doi.org/10.4049/ jimmunol.173.11.6521

-Zaki AA, Attia MM, Ismael E, Mahdy OA (2021) Prevalence, genetic, and biochemical evaluation of immune response of police dogs infected with Babesia vogeli. Vet. World. 14(4): 903-912. https://doi.org/10.14202/vetworld.2021.903-912 